\title{
DEVELOPMENT CUSTOMER KNOWLEDGE MANAGEMENT (CKM) MODELS IN PURBALINGGA HOSPITALITY USING SOFT SYSTEMS METHODOLOGY (SSM)
}

\author{
Nur Chasanah ${ }^{1}$, Dana Indra Sensuse ${ }^{1}$ and Jonathan Sofian Lusa ${ }^{1,2}$ \\ ${ }^{1}$ Fakultas Ilmu Komputer, Universitas Indonesia \\ ${ }^{2}$ Fakultas Teknologi Informasi, Ilmu Komputer, Universitas Budi Luhur \\ E-mail : nurchasanah.1303@gmail.com
}

\begin{abstract}
Development of the tourism sector is part of the national development efforts that are being implemented in Indonesia. This research was conducted with the customer to make an overview of knowledge management models to address the existing problems in hospitality in the hospitality Purbalingga as supporting tourism Purbalingga. The model depicts a series of problem-solving activities that result in the hospitality, especially in Purbalingga. This research was action research with methods of Soft Systems Methodology (SSM) with validation using a theoretical approach, expert judgment and user on the object of research. From the research conducted, has produced a model of customer knowledge management in the hospitality tailored to the problems and needs of the hospitality in Purbalingga.
\end{abstract}

Keywords: customer knowledge management, customer relationship management, knowledge management, soft system methodology, hospitality.

\begin{abstract}
Abstrak
Pembangunan sektor pariwisata merupakan bagian dari upaya pembangunan nasional yang sedang dilaksanakan di Indonesia. Perkembangan sektor pariwisata berkembang sangat pesat, terlihat dari banyaknya wisatawan domestik dan mancanegara yang datang ke Indonesia, seperti ke Purbalingga, Jawa Tengah. Hotel merupakan salah satu sarana akomodasi yang memiliki peranan penting dalam perkembangan industri pariwisata. Seiring dengan pergeseran model pemasaran yang saat ini mengarah pada customer, hotel membutuhkan sebuah model Customer Knowledge Management (CKM) untuk meningkatkan kualitas hotel dan mendukung pariwisata, khususnya di Purbalingga. Berdasarkan studi literatur yang telah dilakukan, hotel merupakan contoh pasar ideal dimana keuntungan didapatkan dari pengimplementasian Customer Relationship Management (CRM). Agar penerapan CRM dapat dilakukan secara maksimal maka diperlukan adanya Knowledge Management (KM) khususnya mengenai customer knowledge pada perhotelan. Oleh karena itu, penelitian ini dilakukan dengan membuat gambaran model Customer Knowledge Management untuk mengatasi permasalahan yang ada pada perhotelan di Purbalingga untuk mendukung pariwisata, sehingga dapat ikut berkontribusi pada perkembangan pariwisata di Indonesia. Penelitian ini merupakan research action dengan metode Soft System Methodology (SSM) untuk menemukan cara terbaik dalam menghadapi situasi yang harus dihadapi dalam kehidupan sehari-hari, khususnya dalam menghadapi permasalahan pada perhotelan di Purbalingga. Validasi yang dilakukan untuk penelitian ini antara lain menggunakan pendekatan secara teoritis, expert judgement dan user pada objek penelitian. Dari penelitian yang dilakukan, dihasilkan sebuah model Customer Knowledge Management pada perhotelan di Purbalingga dan rekomendasi yang disesuaikan dengan permasalahan dan kebutuhan pada perhotelan di Purbalingga.
\end{abstract}

Kata Kunci: customer knowledge management, customer relationship management, knowledge management, soft system methodology, perhotelan.

\section{Introduction}

Tourism has played an important role in the Indonesian economy, especially foreign tourists who provide foreign exchange earnings [10]. In 2009, the tourism sector was ranked third as a foreign exchange earner of 6298.02 million USD [8]. The encouragement of the government to develop the tourism industry in line with the increasing num- ber of tourists coming to Indonesia, the needs of hospitality services is rapidly increasing.

Hotels as one means of accommodation have a significant role in the development of the tourism industry, as it serves as a place to stay for tourists who come for them to travel. Marketing model that has shifted from product-centric to customer-centric company makes, in this case the hospitality to be paying particular attention to the 
customer. In many hotels customer complaint handling is the main feature of customer relationship management.

It has been characterized as a knowledgeintensive and complex process [6]. By including customer knowledge can produce new products according to customer's wishes in order to compete with other companies. Departing from this, it is necessary to do further research to find out how to use customer knowledge management to produce new products in support of the hospitality.

\section{Knowledge}

According to Zack (1999) in modern organizations, knowledge is the fundamental basis of competition and information technology is a critical need to manage knowledge. Distinguish between data, information and knowledge is not easy. In general, the data is a sequence of facts, information organization is a collection of data sets and knowledge is information that has meaning [2].

Knowledge is also defined as a combination of information with experience, context, interprettation and reflection and can be classified into explicit knowledge and tacit knowledge [12]. Knowledge is created when information is transformed into an effective action, in other words, when the information is used and disseminated among the people as well as documented in the form of interaction [7].

\section{Customer Knowledge}

Customer knowledge is increasingly recognized as a key strategic resource in any company's success as it supports R \& D to boost innovation and support the management of long-term customer relationships [3]. The integration of customer knowledge into operational activities is relatively new. Relevant literature differ between knowledge about customers, knowledge of the customer and knowledge for customers [15].

Knowledge about customer: Types of customeroriented knowledge consists of information about the customer regarding the purchase and payment behavior, motivations, habits and demands to buy.

Knowledge from customer: Knowledge of customers arriving at the company's most direct manner. Customers in shaping the organization about his experience with the products, services, and hope.

Knowledge for customer: When customers share their knowledge with other companies, the company is now in a position to identify possible gaps in knowledge and to further develop the customers 'non-knowledge'.

\section{Knowledge Management}

Knowledge management is a process that is required to generate, capture, codify and transfer knowledge throughout the organization to achieve a competitive advantage [1]. The purpose of KM according to Wiig [16] is to make the organization act intelligently to secure the continuity and overall success, as well as to realize the organization that knowledge is the best asset the organization.

\section{Customer Relationship Management}

Briefly defined CRM is a strategy used to learn more about the needs and nature of the customer in order to develop a closer relationship with customers, so companies better understand the requirements desired by customers [3]. While CRM is a business strategy that uses information technology to produce competent firm, reliable and integrated with the customer based on the customer's side so that all the processes and interactions with customers to help maintaining and enhancing relationships profitable relationships [17].

\section{Customer Knowledge Management}

Customer Knowledge Management is the management of knowledge management instruments and procedures applied to support the exchange of customer knowledge within an organization, between organizations and corporate customers, as well as customer knowledge is used to manage customer relationships, to improve customer relationship management processes such as customer service, customer retention and relationship profitability [13].

\section{CKM in Hospitality}

Currently the hospitality industry has a lot of new opportunities, but also many risks that must be considered. Two of the most important opportunities and risks is to have a customer relationship management (CRM) and knowledge management (KM). Both CRM and KM approaches can have a positive impact on reducing costs and increasing revenue.

Improved customer relationships through $\mathrm{KM}$ can generate great business opportunities. In this case improve customer relations through KM is the basis of the creation of customer knowledge management (CKM) in hospitality. The hotel manager came to realize that no hotel can offer all the products and be the best for all customers. They were forced to find a new basis for competition and they have to improve the quality of their own products [18]. 


\section{Methodology}

In this study conducted in hospitality in Purbalingga is still very strong with its culture. The study was conducted at six hotels in Purbalingga by conducting in-depth interviews to managers would also owners of existing hotels in Purbalingga. This study is a qualitative study using descriptive analysis approach. The presence of highly influential researcher for the success of this research.

This study used a soft approach to systems methodology (SSM) using seven steps that must be done so as to produce a model and recommendations will be given to the hospitality to improve service quality and performance of hospitality in Purbalingga.

\section{Problem Situation Considered Problematic}

At this stage do with determining the unstructured problem situation (unstructured problems) to determine the situation existing problems in hospitality in Purbalingga conducted using interviews to issue owner. Issue owner to know this problem is directly related to the day-to-day activities in the hospitality Purbalingga so that the resulting formulation of unstructured problems.
Problem Situation Expressed

At this stage, activities that clearly describes the problems that exist in the real world, in accordance with the reality on the ground resulting in the formulation of the problem is structured and rich picture that illustrates the problems in hospitality in Purbalingga.

\section{Root Definition of Relevant Purposeful Activity} This stage is when thinking about and analyzing the results of a field that has been done before. In findings that have been done before according to the results of data collection techniques and then analyzed focusing on research interest. In this stage, the determination of the root definiton formed using PQR formula. and determine the elements included in the first CATWOE.

Root produced the following definition: "A model of customer knowledge management run by hospitality management actors (Q) in determining reservation, use of guest data, meeting the needs of guests as well as coordination with the environment $(\mathrm{P})$ to make appropriate recommenddations to solve the problems on hospitality in Purbalingga (R)". As well as the resulting analysis in Table CATWOE.

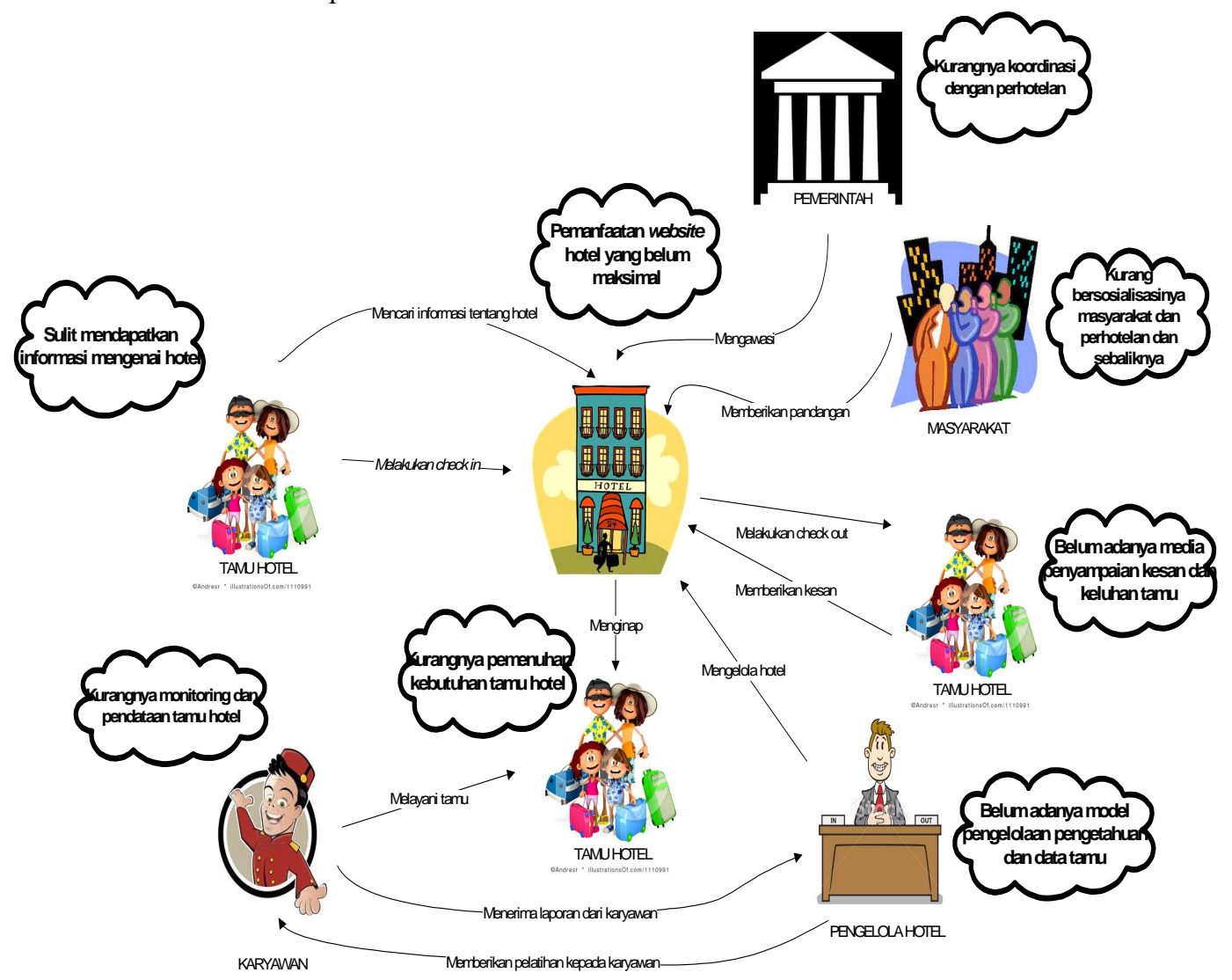

Figure 1. 1 Rich Picture CKM on Hospiality in Purbalingga 


\section{Conceptual Models of the System Named in Root Definition}

According to Williams (2005) conseptual the model is a model that consists of multiple activeties that run the transformation on CATWOE elements. At this stage of purposeful activity and conceptual produced a model of problem solving resulting CKM models in hospitality in Purbalingga.

\section{Comparing Conceptual Model Comparison of Models and Real World}

At this stage it does is compare the conceptual model of the actual circumstances that exist on the object of research. At this stage produces tables provide a comparison with the current activities of the proposed activities and will serve as a recommendation of this study.

\section{Changes; Systemically Desirable Culturally Feasible}

In stage six of the change, the change is a change that is acceptable to the cultural and structural (4). This stage advice, recommendations on the real world and given to the existing system. The resulting recommendations are problem solving or to overcome existing problems, but with a wider scale.

\section{Action to Improve the Problem Situation}

The seventh stage is the last stage of the SSM so that the problems can be considered one cycle has been completed. This stage in the form of action or action that is performed on problem situation. Real actions performed both in conceptual models and assessing feasible and desirable changes in the sixth stage of the SSM on the situation of the problem.

\section{Results and Analysis}

\section{Recommendation}

- The hotel management has planned to construct a website that can provide all the needs of information needed by prospective hotel guests. [17]

- Customer build a data repository that includes a complete history as guest (guest experiences). [14]

- Cultivate customer loyalty and intimacy with implementing service excelant. [8]

- Creating promotions and reward programs to customers, in addition to getting customers, also can strengthen relationships with customers. [3]

- Providing reservation services and online registration for customers to improve the per- formance of hospitality with a membership program that provides convenience and benefits for hotel guests. [3]

- Provides medium to hotel guests give feedback (complaints and impressions) in an effort to provide improvements to the hotel management. [13]

- Provides media and adequate infrastructure for hospitality employees to improve performance in order to build a culture of knowledge sharing. [1]

- Provide media monitoring and evaluation activities in an effort to provide hospitality management hospitality management performance improvement. [17]

- Making monitoring and evaluation agenda scheduling routine (once a week) and incidental emergency meeting to events in order to improve the performance of hospitality. [12]

- Building a performance appraisal system for employees as an evaluation and learning materials to improve the quality and performance of hospitality. [5]

- Cooperating with hospitality agent such as Agoda, booking.com and so on to enhance the promotion of hospitality that guests reach the widest. [15]

- Building a social media between the hospitality with the community by involving the community in the hospitality activities, and vice versa. [12]

- Improve coordination and communication with the government of the hospitality. [11]

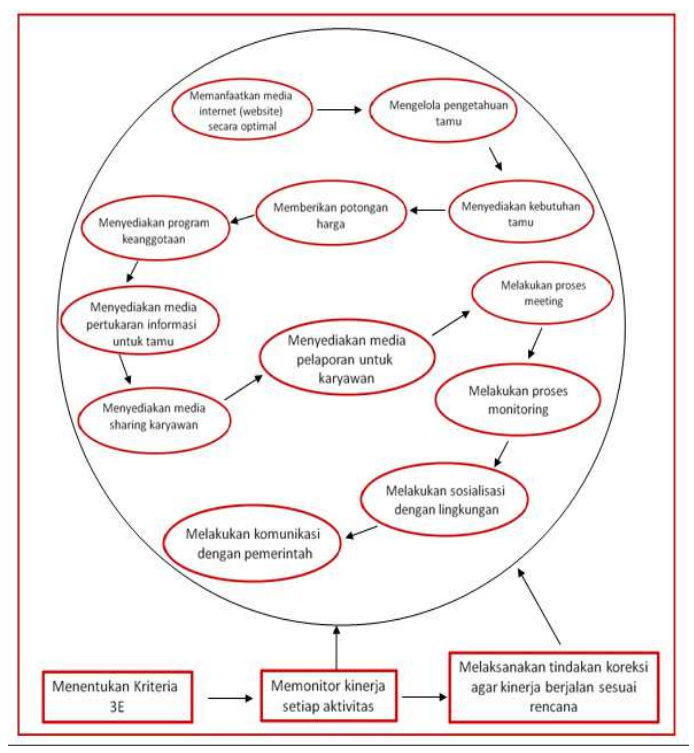

Figure 2. Conceptual Model CKM on Hospitality in Purbalingga 


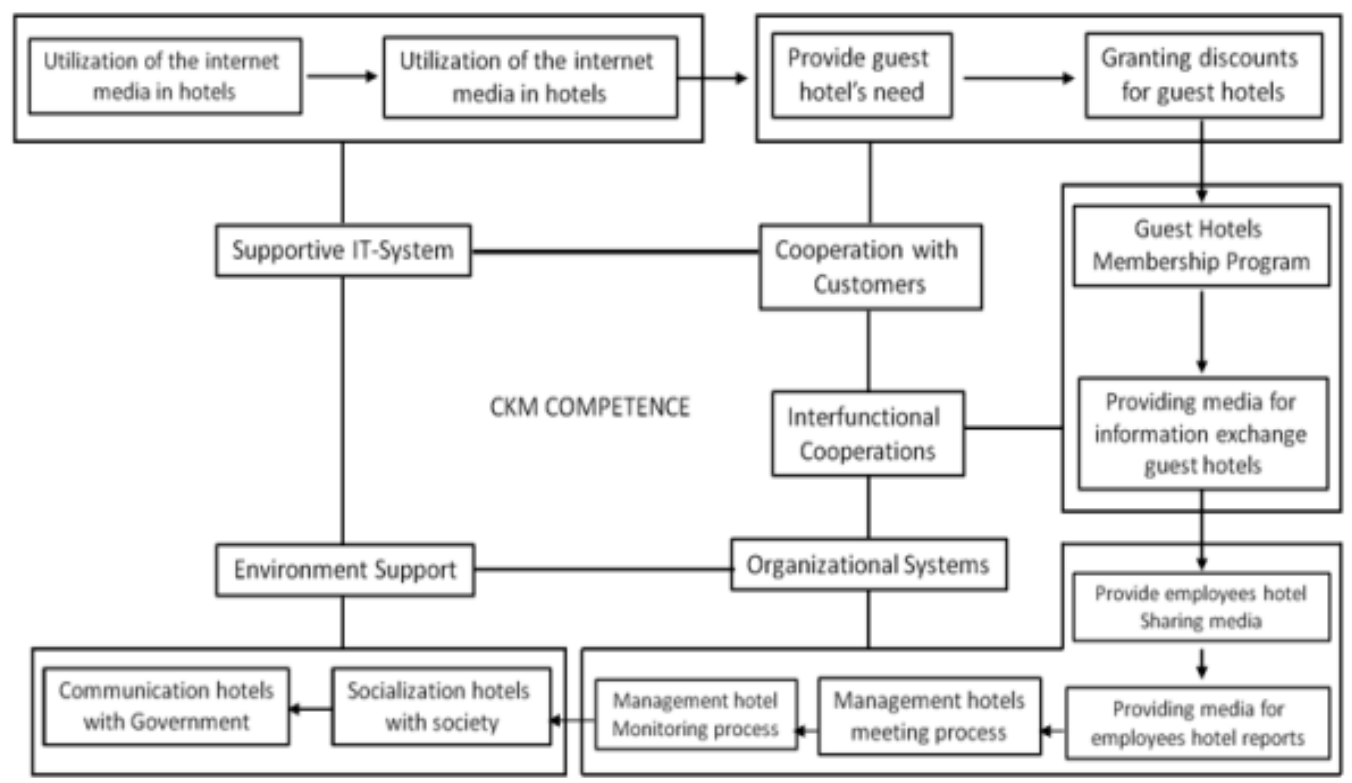

Figure 3. Model CKM on Hospitality in Purbalingga

\section{Validation Result}

Validation of the models is done through theoretical, expert judgment and theoretical user. The adapted to existing theories, expert judgment done to expert and user of hospitality management. From the results of the validation of the model produced more precise as follows in figure 4.4.

Customer Knowledge Management model illustrated in the form of a series of activities into a process for solving problems in hospitality in Purbalingga.

CKM models in hospitality in Purbalingga generated using two approaches, namely Knowledge Management and Customer Relationship Management.

For the KM which is done on the model, among others, to the process of discovery is done on the activities of utilization of the Internet media in hotels, the capture process is done on the activities of management houses the hotel's knowledge, while sharing process carried on activities provide employees hotel sharing media, providing media for employees hotel management activity reports and meeting hotels process, as well as the application process on the KM process performed on hotels monitoring process management activeties, socialization and communication society with hotels with government.

In the model of CKM is also a process of CRM is implemented in some activities on the model, among others, for the acquire (gain custo- mers) do activities provide the guest the hotel's need, to process enhance (bonding) to do activeties granting discounts for guest hotels and guest hotels membership programs, while for the process retain (retain customers) do activities providing media for information exchange houses hotels

\section{Conclusion}

This study aims to determine the problems that occur in hospitality in Purbalingga by developing a model Customer Knowledge Management (CKM) Soft Systems Methodology approach (SSM). The research was conducted by analyzing the existing situation in hospitality in Purbalingga.

In this research, observation and interviews to issue owner. CKM models describe the activities into a process for solving problems in hospitality in Purbalingga and produced with the approach of Knowledge Management and Customer Relationship Management to produce a model of CKM and hospitality recommendations in Purbalingga.

Suggestions for further research is to create Customer Knowledge Management system which is used by the hospitality that all knowledge, knowledge both hotel guests and hotel employees can be has to be better. And also from the model that has been generated can be developed for the hospitality with a wider coverage and a more indepth method on the development of Customer Knowledge Management Model. 


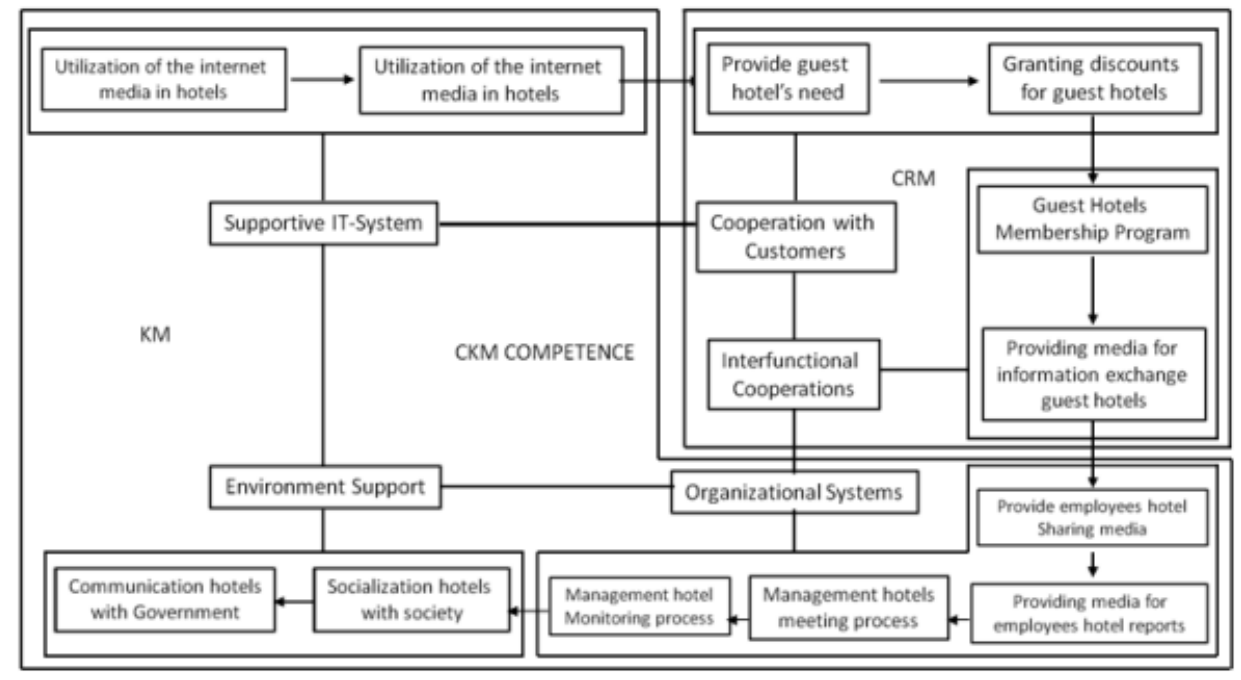

Figure 4. Model Validation Results on the CKM Hospitality in Purbalingga

\section{References}

[1] Becerra, Irma and Rajiv Sabherwal. Knowledg Management Systems and Processes. New York: M.E Sharpe, 2010

[2] Bhatt, G. D. (2001), “Knowledge management in organizations: examining the interaction between technologies, techniques, and people”, Journal of Knowledge Management, vol. 5, no. 1, pp. 68-75.

[3] Buttle F. 2007. Customer Relationship Management Concept and Tools. Jakarta :Bayumedia, hal. 4 - 109

[4] Checkland, Peter and Scholes. 1990. Soft System Methodology in Action. England: John Wiley \& Sons Ltd

[5] Drejer, A. "Organizational learning and competence development." The Learning Organizational (2000): 206-220

[6] Eppler, M., Seifried, P. \&Ropnack, A. 1999, Improving Knowledge Intensive Processes through an Enterprise Knowledge Medium', in Proceedings of Special Interest Group on Computer Personnel Research Annual Conference (SIGCPR), New Orleans, USA, pp. $222-230$

[7] Hennestad, Bjørn (1999). Infusing the organization with customer knowledge. Scandinavian Journal of Management, Vol. 15 , pp. $17-41$

[8] Kalakota, R. and M. Robinson. E-Business 2.0 Roadmap for Success. Massachusetss: Addsion Wesley Longman Inc, 2001.

[9] Kembudpar. Ranking devisa pariwisata terhadap komoditi ekspor. 2010. 15 Januari 2011

http://www.budpar.go.id/page.php?ic=521
[10] Lumaksono, et.al, Dampak Ekonomi Pariwisata Internasional pada Perekonomian Indonesia. 2011

[11] Nonaka,I.(1994).A dynamic theory of organizational knowledge creation. Organization Science, 5(1),14-37

[12] Nonaka, I. and H. A. Takeuchi. The knowledge creating company: How Japanese companies create the dynamics of innovation. New York: Oxford university press, 1995.

[13] Rollins, Minna and Halinen, Aino (2005). Customer Knowledge Management Competence: Towards a Theoretical Framework. Proceedings of the $38^{\text {th }}$ Hawaii International Conference on System Sciences. IEEE

[14] Romano, N. and J. Fjermestad. "Electronic commerce customer relationship management: A research agenda." Information Technology and Management (2003): 233-258.

[15] Wilde, Silvio (2011). Customer Knowledge Management: Improving Customer Relationship through Knowledge Application.p.48. Springer. New York. ISBN: 978-3-642-16474-3

[16] Wiig, Karl (1997). Knowledge Management: An Introduction and Perspective. Journal of Knowledge Management, Vol. 1, No. 1, pp. 6-14

[17] Zikmund, William G. 2003. Customer Relationship Management: Integrating Marketing Strategy and Information Technology, John Willey \& Sons, Inc., United States. 
[18] Zineldin, M., Penelitian dan konsep : Kualitas dan manajemen hubungan pelanggan (CRM) sebagai strategi bersaing dalam industry perbankan Swedia. The TQM Magazine, 17 (4), (2005), 329 -344. 